Thomasius, Christian (1688/2011) Institutes of divine jurisprudence, ed. and trans. T. Ahnert. Indianapolis, Ind.: Liberty Fund.

Wilson, J. (18c/2007) Collected works of James Wilson, ed. K. L. Hall and M. D. Hall. Indianapolis, Ind.: Liberty Fund.
Kate Mertes is a double past-president of ASI, with more years of indexing experience than she cares to calculate. She runs a successful freelance indexing business dedicated to complex scholarly and legal texts. In 2013 she received the Wilson Award for her index to My thoughts (Mes pensées) by Montesquieu. Email: kmertes@hotmai1.com Website: www.katemertes.com

\title{
History indexes reviewed
}

\section{Catherine Sassen}

Catherine Sassen discusses index characteristics mentioned in reviews of history books appearing in Reviews in History and the light the reviews shed on what readers expect of indexes.

\section{Introduction}

Do reviewers care about indexes in history books? Many reviewers quoted in the 'Indexes reviewed' column of The Indexer have voiced strong opinions about the need for highquality indexes in history publications. For example, in a review of The Crimean doctors: a history of the British medical services in the Crimean war, John Fairley (1991) stated that 'careful indexing' is one of the 'hallmarks of sound scholarship.' Reviewers have also indicated that a weak index in a history book can impede the reader's access to information. For example, when discussing Elites in American history: The New Deal to the Carter administration, the reviewer (Economist, 1980) noted, 'the book's usefulness as a work of reference is gravely diminished by a most slovenly index.'

Reviewers have also expressed disdain for history books lacking indexes. For example, in a review of The Himmler brothers, James Grieve (2008) wrote that omitting an index 'surely is a grand way of irritating your readers by impairing their grasp of the narrative and discussion.' Similarly, in a review of The strange death of Scottish history, T. C. Smout (1980) wrote, 'Dr Ash provides food for thought. It is maddening of her publishers not, in turn, to provide an index, so that we could digest it more easily. Fie upon such false economies!'

\section{Literature review}

Few researchers have conducted systematic studies of evaluative comments about indexes in book reviews. Lipetz (1989: 117) examined reviews of nonfiction books in the New York Times Book Review for ten months and found only three that mentioned indexing. Lavell (1990: 60) analyzed 66 book reviews from Archaeological Journal and found only eight mentions of indexing. McFadden (1993: 4-5) studied 206 reviews appearing in Choice in 1988 and 1989. He found that 57 reviews mentioned indexing, and 40 of those reviews included mostly brief evaluative remarks. Dartnell (2007: 186) examined 326 reviews in 11 scientific journals.
She found that 54 reviews included comments on indexing, and only 34 of those comments were evaluative. Sassen (2010: 26-9) analyzed reference book reviews appearing in Booklist, Choice, Library Journal and RUSQ in 2009, and found that only 28.66 percent of the reviews included evaluative remarks about indexes.

There has also been limited research concerning book reviewers' comments about indexes in particular disciplines or genres. Wyman (1999) studied comments about medical indexes that appeared in book review excerpts in the 'Indexes reviewed' section of The Indexer. Sassen (2012) analyzed evaluative remarks by book reviewers of biographies, drawing on reviews excerpted in the 'Reviewed elsewhere' column of Biography.

\section{Methodology}

The goal of this study was to analyze reviewers' comments about indexes in history books. Book reviews from Reviews in History were examined for this purpose. Reviews in History is an electronic journal published by the Institute of Historical Research of the School of Advanced Study at the University of London. The journal began in 1996 with the goal of publishing 'reviews and reappraisals of significant work in all fields of historical interest' (Reviews in History, 2013b). Reviews in History was chosen for this study because it publishes lengthy reviews of 2,000 to 3,000 words, some of which include comments about indexes. The search included reviews appearing in the online journal from 1996 through April 2013.

\section{Limitations}

This content analysis is based on reviews appearing in the Reviews in History electronic journal website during a limited time. It does not constitute an exhaustive study of history book reviews from all journals and newspapers. 
Table I Evaluative comments about indexes

\section{Author's}

decisions Negative Positive Total

\begin{tabular}{lrrrr}
\hline Exhaustivity & 20 & 27 & 20 & 67 \\
Usefulness & & 11 & 12 & 23 \\
Accuracy & 2 & 9 & 2 & 13 \\
Value judgements & & 3 & 8 & 11 \\
Extensiveness & 6 & 3 & 9 \\
Appropriate no. of indexes & & 5 & & 5 \\
Level of analysis & & 2 & 1 & 3 \\
Total evaluative comments & 22 & 63 & 46 & 131 \\
\hline
\end{tabular}

\section{Evaluative comments about indexes}

The 123 reviews included 143 comments about indexes. The number of comments was greater than the number of reviews because some reviews included more than one comment. Of the 143 comments, 12 mentioned the presence of an index, eight noted the absence of an index, and 131 were evaluative. A breakdown of the evaluative remarks is presented in Table 1 and Figure 1.

\section{Accuracy}

Thirteen comments concerned the accuracy of indexes. For example:

Cambridge University Press: Print, manuscript and the search for order 1450-1830, by David McKitterick (2002, 328 pp.) Rev. by Susie West, Reviews in History, review no. 382. Available at: www.history.ac.uk/reviews/ review/382 (accessed 28 April 2013).

Everything is present and correct, from the title page, to the scholarly apparatus of endnotes, and an index.

Boydell \& Brewer: Episcopal culture in late Anglo-Saxon England, by Mary F. Giandrea (2007, 264 pp.) Rev. by John Blair, Reviews in History, review no. 623. Available at: www.history.ac.uk/reviews/review/623 (accessed 28 April 2013).

In a book so full of useful factual data, it is unfortunate that the index is a little erratic (partly, it seems, because of some change in pagination after the first proofs): on p. 144, for instance, every one of the several names in the footnotes is wrongly indexed. Users will generally find the name they want, but then sometimes face a frustrating hunt.

Two comments about inaccuracies in indexes actually reflected on errors of the authors. For example:

Oxford University Press: Passport to Peking: a very British mission to Mao's China, by Patrick Wright (2010, 352 pp.) Rev. by Chris Connolly, Reviews in History, review no. 1116. Available at: www.history.ac.uk/reviews/ review/1116 (accessed 28 April 2013)

More grievously from a historian's perspective, there are a number of significant factual errors, among which I will draw attention to the more obvious. The Xian Incident is

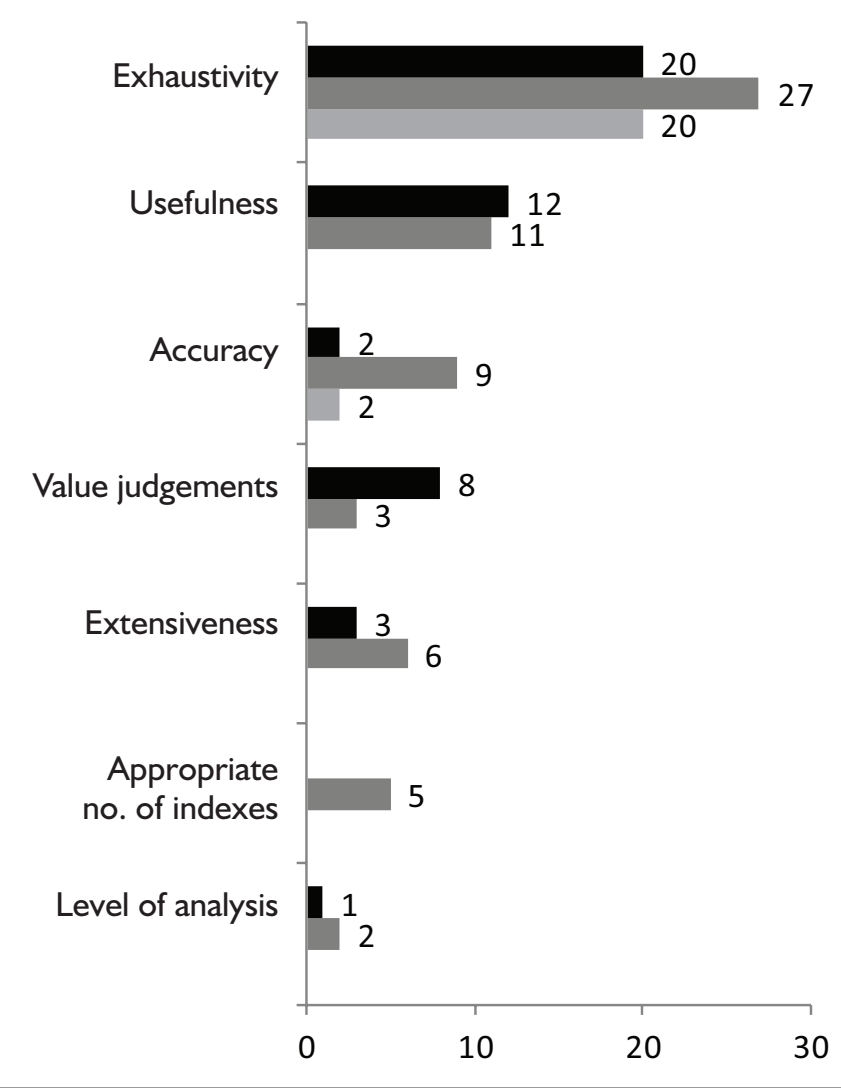

Positive

Negative

Author's decisions

Figure I Evaluative comments about indexes

given as December 1937 (p. 67), though later correctly dated to 1936 (p. 218); side-by-side photographs of Georgian and Uzbek farmers are clearly mislabelled (pp. 152-3); although the author admits that the Long March was 'an alleged (and still disputed) 8,000 miles', (p. 214), four pages later the dispute has reduced it to 'a course of 6,000 miles to Shensi' (p. 218). Ho Chi Minh's Viet Minh is introduced as the Communist League for the Independence of Vietnam (p. 8) (and indexed as such), when of course the word 'Communist' was not in its name, and there were a great many non-communists among its number.

\section{Appropriate number of indexes included?}

Five comments concerned the appropriate number of indexes included in the book. For example:

Boydell \& Brewer: Royal Inauguration in Gaelic Ireland c.1100-1600: a cultural landscape study, by Elizabeth FitzPatrick (2004, 294 pp.) Rev. by Mark Zumbuhl, Reviews in History, review no. 498. Available at: www.history. ac.uk/reviews/review/498 (accessed 28 April 2013).

Oddly, though there are indexes of names (of places, persons and groups) there is no general or subject index. 


\section{Exhaustivity}

Sixty-seven comments concerned the exhaustivity of indexes. For example:

St Martin's Press: Peasants and landlords in later medieval England, c.1380-c.1525, by Edmund Fryde (1996, 382 pp.) Rev. by Mark Ormrod, Reviews in History, review no. 15. Available at: www.history.ac.uk/reviews/ review/15 (accessed 28 April 2013).

Those who persevere will, however, uncover such richness that they will no doubt return many times over, guided by a good thematic index, to draw both on the detailed evidence and on the wise judgements contained therein.

Blackwell Publishing: A companion to contemporary Britain, 1939-2000, ed. by Paul Addison and Harriet Jones (2005, 600 pp.) Rev. by Matthew Grant, Reviews in History, review no. 599. Available at: www.history. ac.uk/reviews/review/599 (accessed 28 April 2013)

The index is nothing less than shocking. A potential reader, if he looked at the index alone, would be left with the impression that there is no mention of, to give a few examples, Enoch Powell, Peter Thorneycroft, Nigel Lawson, or Michael Heseltine. Apparently forgotten Labour figures include Denis Healey, the leaders Hugh Gaitskell, Michael Foot, John Smith, and Neil Kinnock (the relevant part of the index jumps from 'kidney dialysis' to 'Kissinger, Henry'), and Roy Jenkins ('Japanese-style industrial policy' to 'Jewish refugees'). Indexing is a declining art, as publishers naturally seek to reduce costs in a hostile climate, but in a volume of this sort - a 'companion' that is so obviously designed to be a reference or textbook - usability needs to be a priority. If students cannot find what they want in an index, they will go elsewhere for information.

Twenty comments about exhaustivity in indexing concerned decisions made by the authors regarding the scope of their works. For example:

Macmillan: The Bolsheviks and the national question 1917-23, by Jeremy Smith (1999, 304 pp.) Rev. by Raymond Pearson, Reviews in History, review no. 80. Available at www.history.ac.uk/reviews/review/80 (accessed 28 April 2013)

The index significantly contains only five references to the Whites and just three references to the Civil War, a revealing demonstration of the study's tunnel-vision focus on the tortuously Byzantine, occasionally murderously Florentine political intrigues of the new Bolshevik establishment.

Cambridge University Press: Microhistories: demography, society and culture in rural England, 1800-1930, by Barry Reay (1996, 288 pp.) Rev. by Andrew Hinde, review no. 32. Available from: www.history.ac.uk/reviews/ review/32 (accessed 28 April 2013)

Second, nowhere in Microhistories is the impact of population mobility on any of the aspects of social life Reay analyses the subject of any serious discussion. Indeed, neither 'migration' nor 'mobility' appear in the index!

\section{Extensiveness}

Nine comments concerned the extensiveness of indexes. For example:

Penguin: The command of the ocean: a naval history of Britain, 1649-1815, by N. A. M. Rodger (2004, 972 pp.) Rev. by Andrew Lambert, Reviews in History, review no. 446. Available at: www.history.ac.uk/reviews/ review/446 (accessed 28 April 2013)

The scholarly apparatus are [sic] equally powerful, which is exactly what is required in a work that will be consulted for decades by students and scholars ignorant of the basics, and needing the guidance it offers. The index of Command runs to forty pages, the sources to ninety, the endnotes one hundred, and the glossary thirty.

Princeton University Press: $A$ tale of two monasteries: Westminster and Saint-Denis in the thirteenth century, by William Chester Jordan (2009, 266 pp.) Reviewed by Andrew Abram, Reviews in History, review no. 836. Available at: www.history.ac.uk/reviews/review/836 (accessed 28 April 2013)

Similarly, at three pages the index is all too brief and an expanded version might have been more useful to the reader.

\section{Level of analysis}

Three comments concerned the level of analysis of indexes. For example:

Yale University Press: The second crusade: extending the frontiers of Christendom, by Jonathan Phillips (2007, 336 pp.) Rev. by Susan Edgington, Reviews in History, review no. 752. Available at: www.history.ac.uk/reviews/ review/752 (accessed 28 April 2013)

The index is usefully provided with sub-entries.

Oxford University Press: No turning back: the peacetime revolutions of post-war Britain, by Paul Addison (2010, 449 pp.) Rev. by Brian Harrison, Reviews in History, review no. 1040. Available at: www.history.ac.uk/reviews/ review/1040 (accessed 28 April 2013)

The bibliography is reduced to a mere two pages of 'further reading', and although the index is reasonably differentiated, where is the reader who will sweat through 15 entries on 'Conservative party and governments'?

\section{Usefulness}

Twenty-three comments concerned the usefulness of indexes. For example:

Palgrave Macmillan: The material letter in early modern England: manuscript letters and the culture and practices of letter-writing, 1512-1635, by James Daybell (2012, 376 pp.) Rev. by Harry Newman, Reviews in History, review no. 1354. Available at: www.history.ac.uk/reviews/ review/1354 (accessed 28 April 2013) 
For many students and scholars, the book will serve as a valuable reference work, and its generous index means it can easily be used as such.

Yale University Press: English shops and shopping: an architectural history, by Kathryn Morrison (2004, 348 pp.) Rev. by Claire Walsh, Reviews in History, review no. 457. Available at: www.history.ac.uk/reviews/review/457 (accessed 28 April 2013)

The index is not always as helpful as it should be (for example, Dyers's draper's shop of Ilminster can only be located under Ilminster) and illustration references in the index lead to the page number and not to the illustration number, even though there are often several illustrations on one page.

\section{Value judgement}

Eleven comments included value judgements on indexes. For example:

Cambridge University Press: German colonialism: a short history, by Sebastian Conrad (2011, 246 pp.) Rev. by Simon Constantine, Reviews in History, review no. 1268. Available at: www.history.ac.uk/reviews/review/1268 (accessed 28 April 2013)

First published as Deutsche Kolonialgeschichte in 2008, German Colonialism is actually much improved in its new, English form. Unlike the original stripped-down German edition, it is now referenced, and there is also both a fuller and annotated bibliography, and (like Gründer's book) it now contains a proper index - a significant improvement on the short list of place names in the Beck edition.

Oxford University Press: A European experience of the Mughal Orient: the I'jaz-i Arsalani (Persian letters, 17731779) of Antoine-Louis-Henri Polier, trans. by Muzaffar Alam and Seema Alavi (2001, 438 pp.) Rev. by Peter Marshall, Reviews in History, review no. 255. Available at: www.history.ac.uk/reviews/review/255 (accessed 28 April 2013).

The index to this volume is perfunctory in the extreme.

\section{Absence of index noted}

The absence of an index was mentioned in eight comments. For example:

Ausonius: Le monde de l'Itinérance. Le contrôle de la mobilité des personnes en Méditerranée de l'antiquité à l'époque moderne III, ed. by Claudia Moatti, Wolfgang Kaiser and Christophe Pébarthe (2009, 710 pp.) Rev. by Peregrine Horden, Reviews in History, review no. 1016. Available at: www.history.ac.uk/reviews/review/1016 (accessed 28 April 2013).

Nor, in this collection, is there an index of any kind, let alone the type really needed, a thematic one - to aid the reader in choosing alternative paths through its contents.

\section{Discussion}

What do reviewers notice about indexes in history books? According to the results of this study, they assess exhaustivity, usefulness, accuracy and extensiveness most often. They also evaluate the types of indexes included, and the level of analysis of indexes.

It should not be a surprise that exhaustive indexing is mentioned in book reviews, as it is emphasized in indexing instructions found in books about history authorship. For example, in Researching and writing history, David Dymond (1999: 81) wrote, 'an index should cover persons, places and subjects (sometimes expressed as Nominum, Locorum and Rerum). The first two are often combined because they overlap, but the third is the most important, the most frequently omitted and the most difficult to achieve.'

In How to do local history, Gavin McLean (2007: 79) noted that in indexing, the 'secret to success remains the inclusion of concepts and generic terms (politics, education, etc.) along with the more obvious names of people, institutions and places.'

In The Modern Researcher, Jacques Barzun and Henry F. Graff (2004: 290) stated, 'The index is the book reduced to its themes and topics in detail. ... The degree of detail in an index varies not with your inclination but with your subject matter.'

Sandy Topping (1998: 18) wrote that in a history text, 'the who, what and where form the primary structure of its index.' She continued, 'Generally, all names mentioned in a history textbook are indexed - even those mentioned in passing - because it is usually a publisher's (or author's) requirement.'

An interesting finding of this study was the number of comments about indexes that actually reflected on the work of authors, not indexers. Most of these comments concerned the scope of the books, while a few concerned accuracy. For example, in the reviews of The Bolsheviks and the National Question 1917-23 and of Microhistories: demography, society and culture in rural England, 1800-1930 quoted above, each reviewer referred to the index when making complaints about the scope of the book. Each reviewer expected the index to represent the contents of the book fully and accurately, and pointed to the absence of entries in the index when the scope of the book did not meet their expectations.

Indexers should be aware that many readers may rely on the index to access the text of a history book, and may base their judgment of the book on their experience with the index. As Margie Towery (1997) noted, 'The most important thing is to provide a good index for the book, for many people will approach the text only through the index, to glean the precise information they need (not something authors like to hear, but true nonetheless).'

In Researching and writing history, David Dymond (1999: 80) wrote, 'In a substantial book, the discerning reader deserves an index.' If an index to a history book provides exhaustive, accurate and useful access to names of persons, institutions, places, events and concepts, it is indeed fit for a discerning reader. 


\section{Bibliography}

Barzun, J. and Graff. H. F. (2004) The modern researcher, 6th edn. Belmont, Calif.: Thomson Wadsworth.

Dartnell, J. (2007) 'Scientific book reviews: how much do indexes matter?' The Indexer 25(3), 186.

Dymond, D. (1999) Researching and writing history: A practical guide for local historians, 1st edn. Salisbury: British Association for Local History.

Economist (1980) Review of Elites in American history: The New Deal to the Carter administration, by P. H. Burch, Jr. 8 Nov., quoted in 'Indexes reviewed,' The Indexer (1981) 12(4), 219.

Fairley, J. (1991). Review of The Crimean doctors: a history of the British medical services in the Crimean war, by J. Shepherd. British Medical Journal 302, 4 May, quoted in 'Indexes reviewed,' The Indexer (1991) 17(4), 288.

Grieve, J. (2008). Review of The Himmler brothers, by K. Himmler, trans. from German by M. Mitchell. Canberra Times, 9 Feb., quoted in 'Indexes reviewed,' The Indexer (2008) 26(2), 91.

Lavell, C. (1990) 'Indexes, mentions of, by reviewers', letter. The Indexer 17(1), 60.

Lipetz, B.-A. (1989) 'The usefulness of indexes,' in B. H. Weinberg (ed.), Indexing: The state of our knowledge and the state of our ignorance, Medford, N.J.: Learned Information.

McFadden, T. (1993) 'Book reviewers and indexes,' Key Words 1(8), 4-5.
McLean, G. (2007) How to do local history: Research, write, publish, a guide for historians and clients. Dunedin, New Zealand: Otago University Press.

Reviews in History (2013a) Available at www.history.ac.uk/ reviews/ (accessed 28 April 2013).

Reviews in History (2013b) 'About us' Available at www.history. ac.uk/reviews/about (accessed 28 April 2013).

Sassen, C. (2010) 'Reference book indexes reviewed.' The Indexer 28(1), 26-9.

Sassen, C. (2012) 'Biography indexes reviewed.' The Indexer 30(3), 136-40.

Smout, T. C. (1980) Review of The strange death of Scottish history, by M. Ash. Scotsman, 22 Mar., quoted in 'Indexes reviewed,' The Indexer (1980) 12(2), 103.

Topping, S. (1998) 'Indexing history textbooks', in M. Towery (ed.), Indexing specialties: history, Medford, N.J.: Information Today in association with ASI.

Towery, M. (1997) 'Indexes: A critical component of any successful history book.' $O A H$ Newsletter 25(2). Available at: www. asindexing.org/files/SIGs/HistoryArchaeology/Towery_ on_Indexes.pdf (accessed 28 April 2013).

Wymān, P. (1999) 'Medical indexes reviewed.' The Indexer 21(3), 124-6.

Catherine Sassen is principal catalog librarian at the University of North Texas. Email: Catherine.Sassendunt.edu

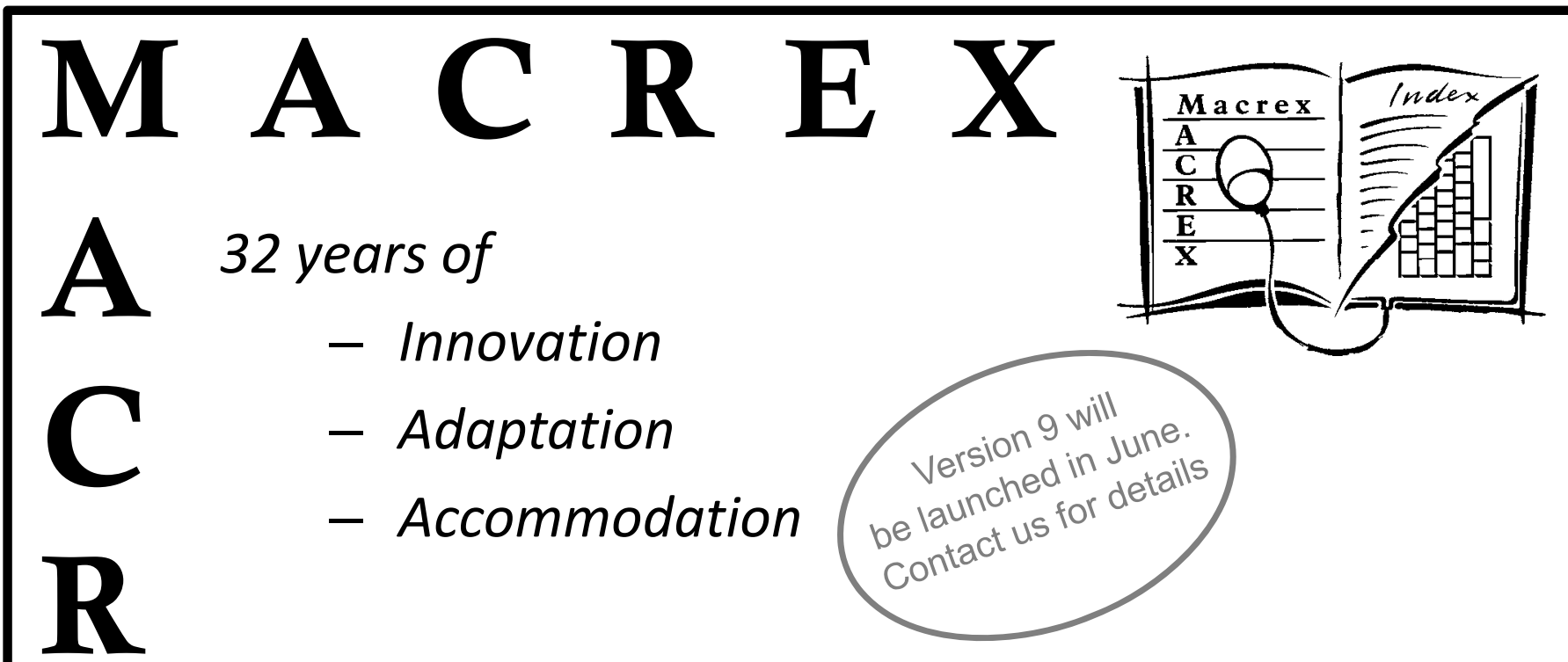

Thriving on the excitement of helping indexers meet the challenges of a changing world since 1981

MACREX Version 9 is a major update designed to provide all the needs of a contemporary indexer working in the digital age

\section{WwW.macrex.com}

